\title{
Biostimulatory effects of simvastatin on MDPC-23 odontoblast-like cells
}

\begin{abstract}
Maria Luísa de Alencar e Silva Leite ${ }^{(a)}$ Diana Gabriela Soares ${ }^{(b)}$ Fernanda Gonçalves Basso ${ }^{(b)}$ Josimeri Hebling(c)

Carlos Alberto de Souza Costa(b)
\end{abstract}

(a) Universidade Estadual Paulista "Júlio de Mesquita Filho" - Unesp, School of Dentistry, Department of Dental Materials and Prosthodontics, Araraquara, SP, Brazil.

(b) Universidade Estadual Paulista "Júlio de Mesquita Filho" - Unesp, School of Dentistry, Department of Physiology and Pathology, São Paulo State University (Unesp), School of Dentistry, Araraquara, SP, Brazil.

(c) Universidade Estadual Paulista "Júlio de Mesquita Filho" - Unesp, School of Dentistry, Department of Orthodontics and Pediatric Dentistry, Araraquara, SP, Brazil.

Declaration of Interests: The authors certify that they have no commercial or associative interest that represents a conflict of interest in connection with the manuscript.

\section{Corresponding Author:}

Carlos Alberto de Souza Costa

E-mail: casouzac@foar.unesp.br

https://doi.org/10.1590/1807-3107BOR-2017.vol31.0104

Submitted: Feb 21, 2017

Accepted for publication: Oct 25, 2017

Last revision: Nov 10, 2017
Abstract: The aim of this study was to evaluate the bioactivity and cytocompatibility of simvastatin (SV) applied to MDPC-23 odontoblast-like cells. For this purpose, MDPC-23 cells were seeded in 96-well plates and submitted to treatments with 0.01 or $0.1 \mu \mathrm{M}$ of SV for $24 \mathrm{~h}, 72 \mathrm{~h}$ or continuously throughout the experimental protocol. The negative control group (NC) was maintained in DMEM. Cell viability (MTT), ALP activity (thymolphthalein monophosphate), and mineralized matrix deposition (alizarin red) were analyzed at several time points. The data were submitted to ANOVA and Tukey's test $(\alpha=0.05)$. Although cell viability was observed in the groups treated with SV, these groups did not differ from the NC up to 7 days. There was a reduction in cell viability for the groups treated with $0.1 \mu \mathrm{M}$ of SV for $72 \mathrm{~h}$, and submitted to continuous mode after 14 days. A significant increase in ALP activity occurred in the group treated with $0.01 \mu \mathrm{M}$ of SV for $24 \mathrm{~h}$, compared with the NC; however, only the group treated with $0.1 \mu \mathrm{M}$ of SV in continuous mode reduced the ALP activity, in comparison with the NC. After 14 days, only continuous treatment with $0.1 \mu \mathrm{M}$ of SV did not differ from NC, whereas the other experimental groups showed increased mineralized matrix deposition. Thus, it was concluded that low concentrations of simvastatin were bioactive and cytocompatible when applied for short periods to cultured MDPC-23 odontoblast-like cells.

Keywords: Guided Tissue Regeneration; Simvastatin; Odontoblasts.

\section{Introduction}

Simvastatin (SV) belongs to the group of statins also known as inhibitors of 3-hydroxy-3-methylglutaryl coenzyme A reductase (HMG-CoA).1,2 This class of drug can inhibit HMG-CoA reductase from turning into mevalonic acid, and is widely used for hyperlipidemia treatment. ${ }^{1,2}$ Several researchers have demonstrated that SV has pleiotropic effects, including anti-inflammatory action, ${ }^{2,3}$ induces angiogenesis and improves the function of endothelial cells, $, 5,5,6,7,8$ as well as enhancing the synthesis and mineralization of bone $e^{9,10,11,12,13}$ and dentin ${ }^{6,14,15,16,17}$ matrices.

The pathway for SV mediating osteo/odontogenic differentiation is not fully known. ${ }^{18}$ However, this phenomenon has been found to be related to activation of the MAPK/ERK signaling pathway, a mechanism similar to that promoted by growth factors such as TGF-b and BMP-2. ${ }^{18}$ The ERK 
pathway is an essential mediator in cell proliferation and differentiation, as well as in bone, periodontal ligament and dental pulp cells. ${ }^{19,20}$ Previous studies have shown that the expression of odontoblastic phenotype, associated with intense mineralized matrix deposition, is dependent on the concentration of SV applied to cells, and that this phenomenon is more pronounced when low concentrations of SV $(0.01$ to $0.1 \mu \mathrm{M})$ are used, in comparison with high concentrations of SV (1 to $10 \mu \mathrm{M})$, which cause cytotoxic effects. ${ }^{6,14,18}$ The positive effect of $\mathrm{SV}$ as a co-adjuvant in direct pulp capping has recently been assessed. ${ }^{21,22}$ Although Asl Aminabadi et al. (2013) ${ }^{21}$ demonstrated that $1 \mu \mathrm{M} \mathrm{SV}$ caused deposition of a mineralized barrier on the exposed pulp tissue of primary human teeth, Jia et al..$^{22}$ showed that this SV concentration was capable of inducing dentin regeneration after pulpotomy in dog teeth.

In view of the potential of $S V$ to induce or accelerate reparative dentinogenesis, a hypothesis emerged that this drug may also have positive pleiotropic effects on odontoblasts; this would indicate the use of this drug as a co-adjuvant in indirect pulp capping (IPC). In cases of very deep cavities, the goal of IPC is to induce fast and effective deposition of reactionary dentin by odontoblasts related to the cavity floor, thus reducing the risk of toxic agents from restorative materials and/or microorganisms reaching the pulp space by transdentinal diffusion. ${ }^{23,24}$ Therefore, the aim of this in vitro study was to evaluate the bioactive potential of simvastatin on odontoblast-like cells, according to the concentrations studied and different contact time intervals. The null hypothesis was that neither concentration nor contact time would influence the bioactive potential of simvastatin on odontoblast-like cells.

\section{Methodology}

\section{Cell Culture}

Immortalized MDPC-23 odontoblast-like cells, derived from rat dental papillae cells $\mathrm{s}^{25}$, were cultivated (T0) in Dulbecco's Modified Eagle's Medium (DMEM, Sigma Chemical Co., St. Louis, MO, USA) supplemented with 10\% fetal bovine serum (FBS; GIBCO, Grand Island, NY, USA), $100 \mathrm{IU} / \mathrm{mL}$ penicillin, $100 \mu \mathrm{g} / \mathrm{mL}$ streptomycin and $2 \mathrm{mmol} / \mathrm{L}$ glutamine (GIBCO, Grand Island, NY, USA) at $37^{\circ} \mathrm{C}$, with $5 \% \mathrm{CO}_{2}$ and $95 \%$ air (Isotemp Fisher Scientific, Pittsburgh, PA, USA). ${ }^{26}$

\section{Experimental Procedure}

Cells in complete DMEM (containing 10\% FBS) were seeded in 96-well plates, at a density of 2,500 cells/well, at $37^{\circ} \mathrm{C}$ and $5 \% \mathrm{CO}_{2}$ for $24 \mathrm{~h}$. After this period, the cells at $70 \%$ confluence were submitted to different treatments (T1), according to the experimental groups (Table 1).

Table 1. Experimental groups according simvastatin (SV) concentration and treatment period

\begin{tabular}{lcc}
\hline Group & SV Concentration & Treatment period \\
\hline Negative Control (NC) & - & Continuous \\
SV $0.01-24 \mathrm{~h}$ & $0.01 \mu \mathrm{M}$ & 24 hours \\
SV $0.01-72 \mathrm{~h}$ & $0.01 \mu \mathrm{M}$ & 72 hours \\
SV 0.01 - Cont. & $0.01 \mu \mathrm{M}$ & Continuous \\
SV $0.1-24 \mathrm{~h}$ & $0.10 \mu \mathrm{M}$ & 24 hours \\
SV $0.1-72 \mathrm{~h}$ & $0.10 \mu \mathrm{M}$ & 72 hours \\
SV 0.1 - Cont. & $0.10 \mu \mathrm{M}$ & Continuous \\
\hline
\end{tabular}

Hence, the cells were incubated in complete DMEM, supplemented either with or without SV (Sigma Chemical Co, Saint Louis, MO USA), up to 14 days. In the groups treated with simvastatin for $24 \mathrm{~h}$ and $72 \mathrm{~h}$, the cells were cultivated in culture medium after the contact time, with noSV up to the periods of analysis (5, 7 and 14 days). In the groups with continuous SV treatment, the cells were cultivated in DMEM plus $\mathrm{SV}$ throughout the experimental period. For the negative control group (NC), the cells were cultivated in complete DMEM. The experimental design is demonstrated in Figure 1. The tests were performed according to ISO 10993-5:2009 (E) ${ }^{27}$ recommendations, and the data collected by MTT assay were classified according to this standard (Table 2).

\section{Cell Viability}

Cell viability was evaluated by the MTT assay ( $\mathrm{n}=6$ ) after 1 (T2), 3 (T3), 7 (T5) and 14 (T6) days. The cells were incubated for $4 \mathrm{~h}$ in DMEM supplemented with $10 \%$ MTT solution $(5 \mathrm{mg} / \mathrm{ml}$; Sigma Chemical 


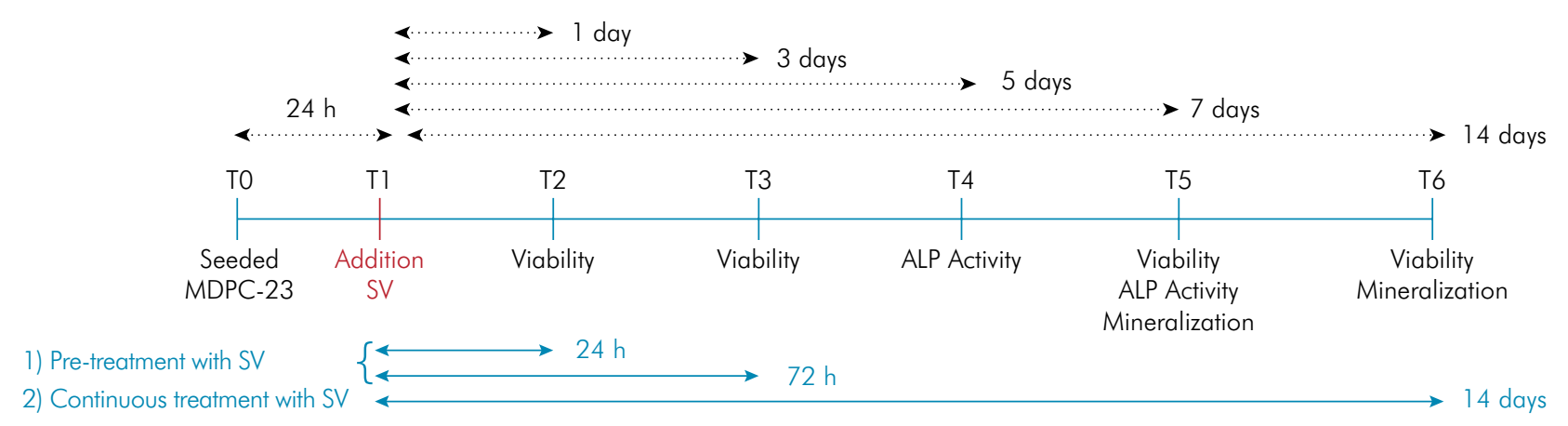

Figure 1. Experimental design.

Table 2. Grade of cytotoxicity according with ISO 10993-5:2009 (E).

\begin{tabular}{lcc}
\hline Grade & Reactivity & Culture conditions \\
\hline 0 & None & No cell lysis, no reduction in cell growth \\
1 & Slight & Not more than $20 \%$ reduction in cell growth \\
2 & Mild & Not more than $50 \%$ reduction in cell growth \\
3 & Moderate & Not more than $70 \%$ reduction in cell growth \\
4 & Severe & Nearly complete or complete destruction of \\
& & cell layers \\
\hline
\end{tabular}

Co, Saint Louis, MO, USA) at each time point. After this period, the formazan crystals were dissolved in $200 \mu \mathrm{L}$ of acidified isopropanol solution (Quemis, Indaiatuba, SP, Brazil), and absorbance was measured at $570 \mathrm{~nm}$ (Synergy H1, Biotek, Winooski, VT, USA). ${ }^{26}$ The data were standardized according to the NC group (mean absorbance $=100 \%$ cell viability).

\section{ALP Activity}

ALP activity was evaluated by the thymolphthalein monophosphate test $(n=6)$ at 5 (T4) and 7 (T5) days, by means of the Alkaline Phosphatase Endpoint Assay (Labtest Diagnóstico S.A., Lagoa Santa, Minas Gerais, Brazil). A dose of $0.1 \%$ sodium lauryl sulfate (Sigma Chemical Co., Saint Louis, MO, USA) was applied to the cells at each time point, to promote cell lysis. An aliquot of the lysis reaction was transferred to tubes containing thymolphthalein monophosphate $(22 \mathrm{mmol} / \mathrm{L})$ at $37^{\circ} \mathrm{C}$ to quantify the ALP dosage. Afterwards, a color reagent (sodium carbonate $94 \mathrm{mmol} / \mathrm{L}$ and sodium hydroxide $250 \mathrm{mmol} / \mathrm{L}$ ) was added, and the absorbance was measured at $590 \mathrm{~nm}$ (Synergy H1). ALP standardization was performed by quantifying the total protein dosage. Thus, another aliquot of the lysis reaction was transferred to tubes containing Lowry Reagent Solution (Sigma Chemical Co., Saint Louis, MO, USA), which remained in contact for $20 \mathrm{~min}$ at $25^{\circ} \mathrm{C}$. After this, Folin and Ciocalteau's Phenol Reagent solution (Sigma Chemical Co., Saint Louis, MO, USA) was added, and remained in contact for $30 \mathrm{~min}$, after which absorbance was measured at $655 \mathrm{~nm}$ (Synergy H1). The doses of ALP and total protein were obtained from a standard curve, and the ALP activity value was calculated by dividing the ALP dosage values by those of total protein. ${ }^{28}$ The NC group was considered as $100 \%$ of ALP activity.

\section{Mineralized Matrix Deposition}

Mineralized matrix deposition was evaluated by the Alizarin Red test $(n=6)$ at 7 and 14 days. At each time point, the cells were fixed with $70 \%$ ethanol at $4^{\circ} \mathrm{C}$ for $1 \mathrm{~h}$, followed by washing with deionized water, and incubation with Alizarin Red solution (40 mM, pH 4.2; Sigma Chemical Co., Saint Louis, $\mathrm{MO}$, USA) for 15 min under agitation. After this period, the cells were washed with deionized water, and the formation of nodules was evaluated by light microscope (Olympus BX51TF, Tokyo, Japan). Images of mineralization nodule formation were obtained at $4 \mathrm{X}$ magnification. Afterwards, a cetylpyridinium chloride solution (10 mM, pH 7.0; Sigma Chemical Co., Saint Louis, MO, USA) was applied for $15 \mathrm{~min}$ to dissolve the nodules, and absorbance of the resultant solution was evaluated at $560 \mathrm{~nm}$ (Synergy H1). ${ }^{28}$ The mean absorbance value of the NC group was considered as $100 \%$ of mineralized matrix deposition. 


\section{Data Analysis}

Two independent experiments were performed to guarantee reproducibility of the data that were tabulated and submitted to Kolmogorov-Smirnov test to verify normality. Since the data were normal, they were analyzed by two-way ANOVA, complemented by the Tukey test $(p<0.05)$. SPSS 19.0 software (SPSS Inc., Chicago, IL, USA) was used to perform the statistical analyses.

\section{Results}

\section{Cell Viability}

As observed in Figure 2, there was a significant increase in cell viability for all experimental groups throughout the time points $(\mathrm{p}<0.0001)$. There was no significant difference among the experimental groups exposed to SV, compared with the NC group, at 1,3 and 7 days, irrespective of SV concentration and treatment time $(p>0.05)$. However, treatment with $0.1 \mu \mathrm{MSV}$ for $72 \mathrm{~h}(\mathrm{p}<0.0001)$ or in continuous mode $(p=0.0003)$ significantly reduced cell viability in comparison with NC at the 14-day time point. On the other hand, considering ISO 10993-5:2009 classification, this reduction represents only slight cytotoxicity, as shown in Table 3.

\section{ALP Activity}

A slight enhancement in ALP activity was observed for all the groups in which the cells were exposed to SV, in comparison with NC at 5 days (Figure 3); nevertheless, this increase was significant only for the cells treated with $0.01 \mu \mathrm{M}$ for $24 \mathrm{~h}$ ( $\mathrm{p}<0.0001)$. At 7 days, significant reduction in ALP activity was observed, in comparison with NC, only for the cells exposed to $0.1 \mu \mathrm{M}$ in continuous mode $(\mathrm{p}<0.0001)$.

Table 3. Classification of cytotoxicity of the experimental groups at each time point, according to ISO 10993-5:2009 (E).

\begin{tabular}{|c|c|c|c|c|c|c|c|c|}
\hline \multirow[b]{2}{*}{ Group } & \multicolumn{2}{|c|}{1 day } & \multicolumn{2}{|c|}{3 days } & \multicolumn{2}{|c|}{7 days } & \multicolumn{2}{|c|}{14 days } \\
\hline & $\begin{array}{l}\% \text { cell viability } \\
\text { reduction* }\end{array}$ & $\begin{array}{c}\text { Toxicity } \\
\text { classification** }\end{array}$ & $\begin{array}{l}\% \text { cell viability } \\
\text { reduction }\end{array}$ & $\begin{array}{c}\text { Toxicity } \\
\text { classification }\end{array}$ & $\begin{array}{l}\% \text { cell viability } \\
\text { reduction }\end{array}$ & $\begin{array}{c}\text { Toxicity } \\
\text { classification }\end{array}$ & $\begin{array}{l}\% \text { cell viability } \\
\text { reduction }\end{array}$ & $\begin{array}{c}\text { Toxicity } \\
\text { classification }\end{array}$ \\
\hline SV $0.01-24 h$ & 8.4 & Slight & 0 & None & 0 & None & 0 & None \\
\hline SV $0.01-72 h$ & 8.1 & Slight & 0 & None & 0 & None & 1.7 & Slight \\
\hline SV 0.01 - Cont & 9.1 & Slight & 0 & None & 0.4 & Slight & 6.1 & Slight \\
\hline SV $0.1-24 h$ & 10.5 & Slight & 0 & None & 0 & None & 6.3 & Slight \\
\hline SV $0.1-72 \mathrm{~h}$ & 10.4 & Slight & 0 & None & 3.7 & Slight & 10.6 & Slight \\
\hline SV 0.1 - Cont & 9.0 & Slight & 0 & None & 8.2 & Slight & 8.8 & Slight \\
\hline
\end{tabular}

${ }^{*}$ values are the mean percentage of cell viability reduction based on the negative control at each time point; ${ }^{* *}$ according to ISO 10993-5:2009 (E)

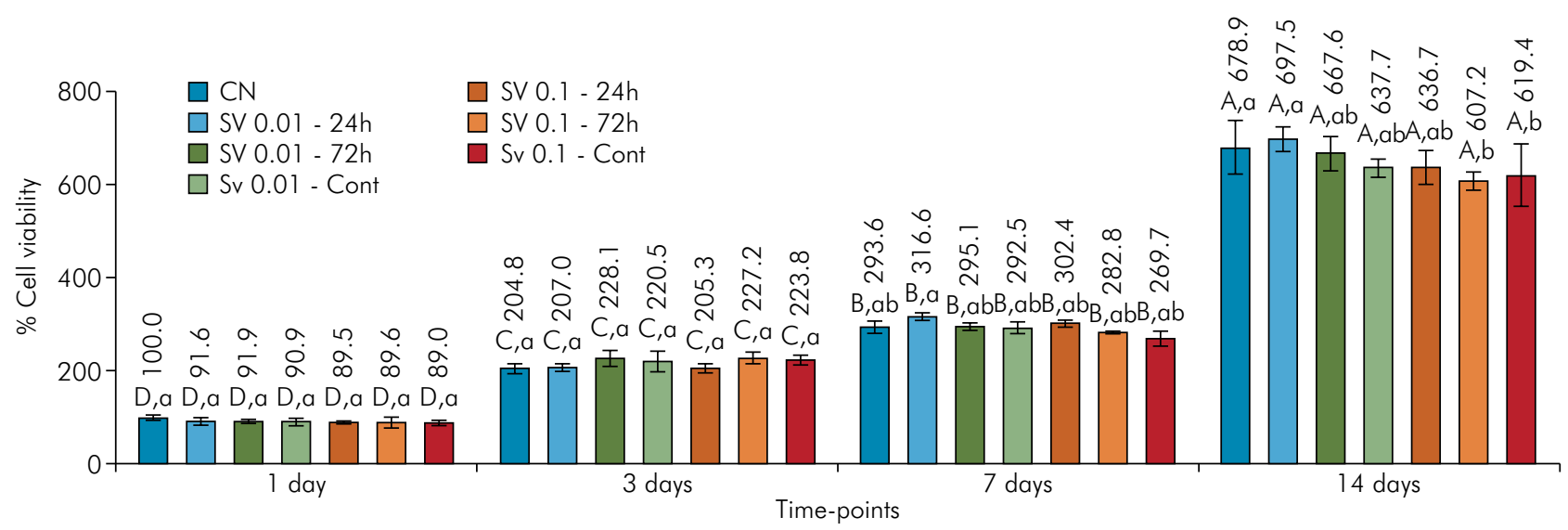

Figure 2. Mean and standard deviation of cell viability values (\%) for each experimental group at the time points. Uppercase letters allow comparison among the time points for each experimental group. Lowercase letters allow comparison among the groups within each time point. Different letters show significant differences $(n=6$; tests: ANOVA and Tukey; $p<0.05)$. 
However, the other groups did not differ statistically when compared with NC ( $p>0.05)$.

\section{Mineralized Matrix Deposition}

An increase of $73.2 \%, 82.4 \%, 56.1 \%, 44.9 \%$ and $30.4 \%$ in mineralized matrix deposition was observed for the groups: SV $0.01-24 \mathrm{~h}(\mathrm{p}<0.0001) ; \mathrm{SV} 0.01-72 \mathrm{~h}$ ( $\mathrm{p}<0.0001) ;$ SV 0.01 - Cont; SV 0.1 - 24 h ( $\mathrm{p}<0.0001)$; and SV $0.1-72 \mathrm{~h}(\mathrm{p}=0.0018)$, respectively, at the 14-day period, in comparison with NC (100\%) (Figure 4). However, the mineralized matrix deposition for these groups was not different from that of NC when MDPC-23 cells were exposed to $0.1 \mu \mathrm{M}$ in continuous mode $(p>0.05)$. Representative images of mineral nodule deposition at 14 days are shown in Figure 5.

\section{Discussion}

The literature has shown that simvastatin is a potent odontogenic differentiation inductor of dental pulp stem cells (hDSPCs cells), with cells featuring intense capability of depositing calcium-rich matrix. ${ }^{6,14,15,16,17,18,29}$ The results observed in the present study seem to corroborate these previous scientific data, since the authors were able to demonstrate that

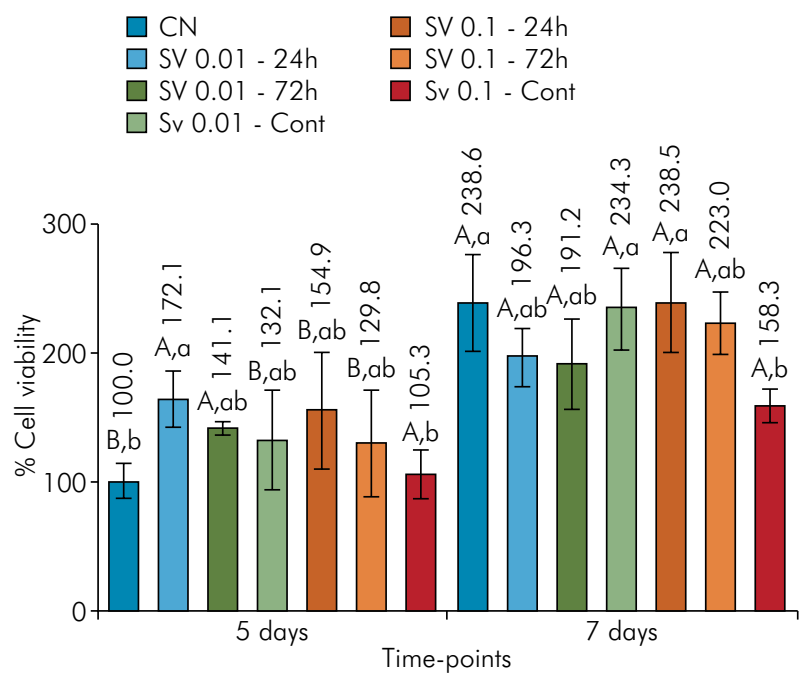

Figure 3. Mean and standard deviation of ALP activity values (\%) for each experimental group at the set time points. Uppercase letters allow comparison among the time points for each experimental group. Lowercase letters allow comparison among the groups within each time point. Different letters show significant differences ( $n=6$; tests: ANOVA and Tukey; $p<0.05$ ). low doses of SV have the potential to biostimulate odontoblast-like cells in vitro. Exposure of MDPC-23 cells to 0.01 and $0.1 \mu \mathrm{M} \mathrm{SV}$ for $24 \mathrm{~h}, 72 \mathrm{~h}$ or in continuous mode caused no cytopathic effect at 1, 3 and 7 days, confirming the results obtained in previous laboratorial investigations, in which the authors used a primary culture of human pulp cells. ${ }^{18,22,30}$ However, the treatment of cells with $0.1 \mu \mathrm{M}$ $\mathrm{SV}$ at $72 \mathrm{~h}$ and in continuous mode decreased the cell proliferation at the later period; under these specific conditions, cell viability values were significantly lower than those of the NC at the 14-day period. Nevertheless, according to ISO 10993-5:2009 (E), the percentage of cell viability reduction mediated by $\mathrm{SV}$ in these groups may be considered slight, since it was less than $20 \%$, compared with the NC.

The MTT assay has limitations regarding the evaluation of cytotoxicity, since it assesses cell viability as a function of redox potential, and therefore measures cell viability indirectly. ${ }^{29}$ For this reason, other assays should be performed to demonstrate if cell viability reduction was mediated by cell death or if there was a reduction in the proliferative potential. Moreover, Saewong et al. ${ }^{29}$ demonstrated that $0.1 \mu \mathrm{M}$ of simvastatin did not

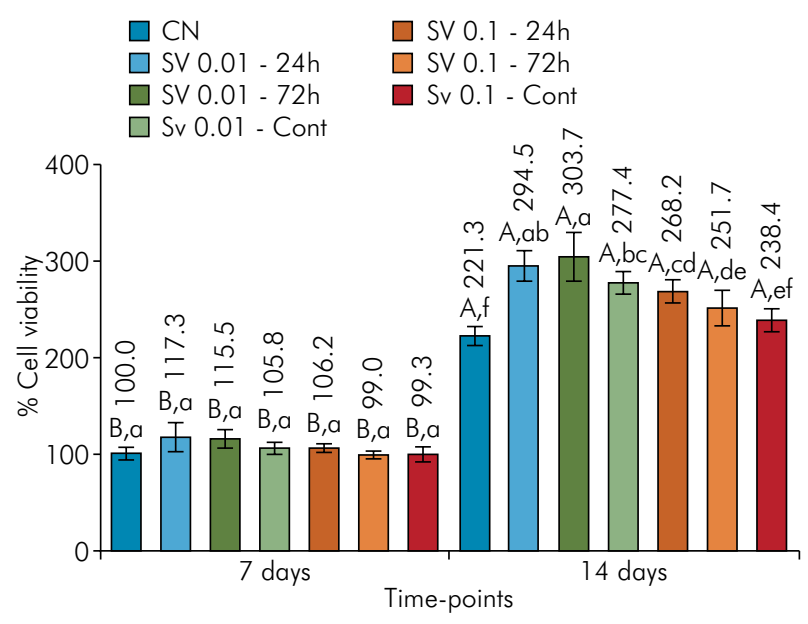

Figure 4. Mean and standard deviation of mineralized matrix deposition values (\%) for each experimental group at the established time points. Uppercase letters allow comparison among the time points for each experimental group. Lowercase letters allow comparison among the groups within each time point. Different letters show significant differences $(n=6$; tests: ANOVA and Tukey; $p<0.05)$. 

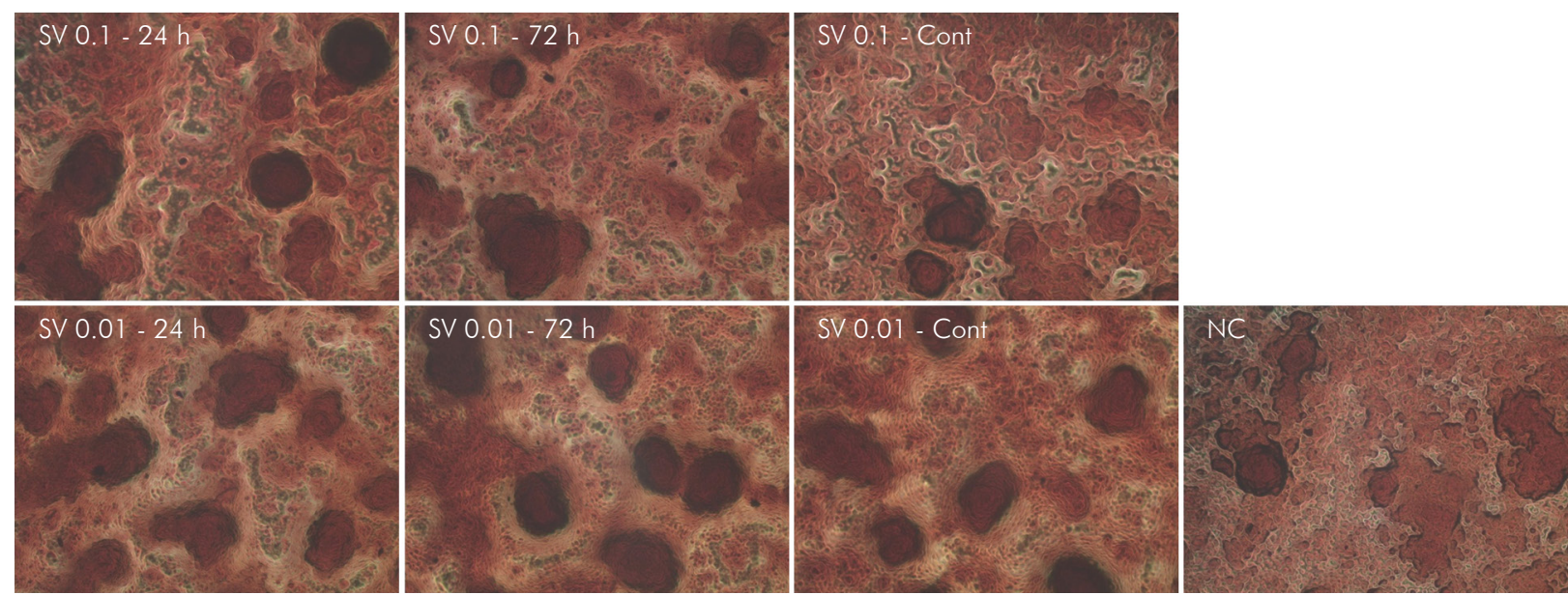

Figure 5. Representative images of the Alizarin Red assay for each group at 14 days (light microscopy, 4X). Note the increased nodule formation for all groups exposed to SV in comparison to NC, except for SV 0.1 in continuous mode, which shows features similar to NC.

reduce cell viability (MTT assay) of HDPCs and periodontal ligament fibroblasts (HPLFs) after 24,48 , and $72 \mathrm{~h}$ incubation time. This finding was corroborated by the other tests performed in this study, which evaluated levels of apoptosis of HDPCs and HPLFs by flow cytometry after Annexin V/propidium iodide double staining, actin cytoskeleton and nuclear morphology by phalloidin-FITC and 40,6-diamidino-2-phenylindole dihydrochloride staining, in which no cell structure damage was observed under these conditions. ${ }^{29}$

Moreover, some researchers have demonstrated a decrease in cell viability mediated by SV for other types of cells, such as smooth muscle cells, ${ }^{31}$ neuronal cells, ${ }^{32}$ bone marrow stem cells (BMSC), ${ }^{33}$ adipose derivate mesenchymal stem cells (AD-MSC) ${ }^{34}$ and hDSPCs cells. ${ }^{22}$ Okamoto et al. ${ }^{14}$ reported that when SV concentrations higher than $1 \mu \mathrm{M}$ were applied to hDSPCs cells, they inhibited the formation of actin fibers and interfered with progression of the cell cycle regulated by the Rho pathway. However, this reduction in cell proliferation was reestablished in the presence of mevalonate. Thus, the authors concluded that the suppression effect caused by SV on hDSPCs cells is mediated by the mevalonate and Rho pathways. Therefore, it was possible to postulate that these same pathways may be related to the reduction in MDPC-23 odontoblast-like cell viability observed in the present study at 14 days.
Regarding the results of ALP activity, we observed that only the treatment with $0.01 \mu \mathrm{M} \mathrm{SV}$ for $24 \mathrm{~h}$ significantly enhanced the activity of this enzyme at the 5-day time point. Some researchers have found greater ALP activity in human pulp cells treated in continuous mode with SV, in the concentrations of 0.01 , $0.1 \mu \mathrm{M}^{6,18}$ and $1 \mu \mathrm{M} \cdot{ }^{15,22}$ This increase in ALP activity observed in human pulp cells treated with SV seems to be related to the induction of odontogenic differentiation by activation of the ERK pathway. ${ }^{18} \mathrm{SV}$ is known to accelerate the expression of bone/dentin differentiation markers, such as ALP, OCN, OPN, Runx-2, Osterix, DSP and DMP-1, when applied to human dental pulp cells. ${ }^{14,15}$ Based on these findings by previous studies, and in agreement with the interesting data obtained in the present research, it could be posited that the pathway activated by SV to biostimulate MDPC-23 odontoblast-like cells would be similar to that observed for hDSPCs cells in culture.

It is known that each cell type presents a threshold of cytocompatibility when exposed to any agent, ${ }^{6,14,30}$ thereby allowing the phenotype expression to be reduced when the concentration and/or time of exposure to the toxic drug exceeds the critical threshold at which the cell can remain viable. ${ }^{18,30}$ This may in part explain the decreased viability accompanied by a reduction in ALP activity of the MDPC-23 cells treated with $0.1 \mu \mathrm{MSV}$ in continuous mode after the time interval of 7 days. 
Regarding mineralized matrix deposition, we observed that the activity of these cells was increased after 14 days, except for the group in which the cells were treated with $0.1 \mu \mathrm{M} \mathrm{SV}$ in continuous mode. The data obtained in the present study do not corroborate the findings of previous investigations carried out by Min et al. ${ }^{6}$, Lee et al., ${ }^{15}$ and Jia et al. ${ }^{22}$, in which the authors demonstrated a greater formation of mineralized matrix in human pulp cells exposed to $1 \mu \mathrm{MSV}$ in continuous mode for 14 days. Okamoto et al. ${ }^{14}$ also related an enhancement in mineralized tissue formation when hDSPCs cells were treated with $0.1 \mu \mathrm{MSV}$ in continuous mode for 7 days, and then transplanted into subcutaneous tissue of immunocompromised rats. In the present study, only those groups in which the cells were exposed to $0.01 \mu \mathrm{MSV}$ for $24 \mathrm{~h}$ and $72 \mathrm{~h}$ presented an enhancement in mineralization nodule formation, indicating that low concentrations of this drug applied for short periods of time can stimulate MDPC-23 cell activity.

According to the data obtained, and considering the methodologic limitations of the tests performed in the present in vitro study, it seems that low-dose SV may be capable of biostimulating mineralized matrix formation, depending on the mode of application and the type of cell exposed to this drug. Wang et al. ${ }^{35}$ evaluated the in vivo effects of direct application of doses of $10 \mathrm{mg} / \mathrm{kg} /$ day SV in regions of bone fracture, and found that this therapy contributed to the local repair process. However, intense inflammatory reaction occurred when the dose of $70 \mathrm{mg} / \mathrm{kg} \mathrm{SV}$ was applied directly to bone defects produced in rat calvaria. ${ }^{34}$ Asl Aminabadi et al. ${ }^{21}$ also found that concentrations of 1 to $5 \mu \mathrm{MSV}$ stimulated mineralized barrier formation in pulp exposures of primary teeth. The authors reported that lower concentrations of SV induced greater dentinal matrix deposition and caused less inflammatory reaction in the pulpal wound area. On the other hand, Stein et al. ${ }^{36}$ observed that only a single application of $0.5 \mathrm{mg}$ SV (incorporated into a methylcellulose gel) in the supraperiosteal region of rat mandibles stimulated bone formation at the site, associated with less inflammatory reaction when compared with higher doses of the same drug. This suggests that low concentrations of SV are not only safe and cytocompatible, but also capable of biostimulating cells with osteo/odontoblast phenotype in the process of mineralized matrix formation. Thus, these positive effects of SV make this drug a potential co-adjuvant for therapies in which bone or dentin are lost, or even in situations of pulp tissue exposure.

Taking into account the scientific data provided in the current literature, and the relevant results obtained in the present study, despite the limitations of this laboratorial investigation, it seems interesting to evaluate the use of SV as a co-adjuvant for IPC in future studies. Incorporation of this drug into traditional or even innovative biomaterials may enhance the bioactivity of this clinical procedure involving the dentin-pulp complex, which is of particular interest for very deep cavities. ${ }^{23,24}$ In this clinical condition, it would be expected that a slow release of a low concentration of SV would be capable of diffusing through the dentinal tubules to biostimulate the subjacent odontoblasts. Moreover, further studies are needed to evaluate whether simvastatin may be used positively as a co-adjuvant treatment in IPC, in order to protect and reestablish the physiological condition of the dentin-pulp complex.

\section{Conclusion}

According to the methodology employed in the present in vitro study, it may be concluded that low concentrations of simvastatin applied for short periods on cultured MDPC-23 odontoblast-like cells increase the metabolism and capability of this cell line to deposit mineralized matrix.

\section{Acknowledgments}

The authors wish to thank the Fundação de Amparo à Pesquisa do Estado de São Paulo - FAPESP (MS: 2015/15635-7) and the Conselho Nacional de Desenvolvimento Científico e Tecnológico - CNPq (grants: 03599/2014 and 443153/2014-0) for their financial support. 


\section{References}

1. Maeda T, Matsunuma A, Kawane T, Horiuchi N. Simvastatin promotes osteoblast differentiation and mineralization in MC3T3-E1 cells. Biochem Biophys Res Commun. 2001;280(3):874-7. https://doi.org/10.1006/bbrc.2000.4232

2. Liao JK, Laufs U. Pleiotropic effects of statins. Annu Rev Pharmacol Toxicol. 2005;45(1):89-118. https://doi.org/10.1146/annurev.pharmtox.45.120403.095748

3. Sakoda K, Yamamoto M, Negishi Y, Liao JK, Node K, Izumi Y. Simvastatin decreases IL- 6 and IL- 8 production in epithelial cells. J Dent Res. 2006;85(6):520-3. https://doi.org/10.1177/154405910608500608

4. Kwak B, Mulhaupt F, Myit S, Mach F. Statins as a newly recognized type of immunomodulator. Nat Med. 2000;6(12):1399-402. https://doi.org/10.1038/82219

5. van Nieuw Amerongen GP, Vermeer MA, Nègre-Aminou $P$, Lankelma J, Emeis JJ, van Hinsbergh VW. Simvastatin improves disturbed endothelial barrier function. Circulation. 2000;102(23):2803-9. https://doi.org/10.1161/01.CIR.102.23.2803

6. Min KS, Lee YM, Hong SO, Kim EC. Simvastatin promotes odontoblastic differentiation and expression of angiogenic factors via heme oxygenase- 1 in primary cultured human dental pulp cells. J Endod. 2010;36(3):447-52. https://doi.org/10.1016/i.joen.2009.11.021

7. Nishimoto-Hazuku A, Hirase T, Ide N, Ikeda Y, Node K. Simvastatin stimulates vascular endothelial growth factor production by hypoxia-inducible factor-lalpha upregulation in endothelial cells. J Cardiovasc Pharmacol. 2008;51(3):267-73. https://doi.org/10.1097/FJC.0b013e3181624b44

8. Xu J, Liu X, Chen J, Zacharek A, Cui X, Savant-Bhonsale S et al. Simvastatin enhances bone marrow stromal cell differentiation into endothelial cells via notch signaling pathway. Am J Physiol Cell Physiol. 2009;296(3):C535-43. https://doi.org/10.1152/ajpcell.00310.2008

9. Ayukawa Y, Yasukawa E, Moriyama Y, Ogino Y, Wada H, Atsuta I et al. Local application of statin promotes bone repair through the suppression of osteoclasts and the enhancement of osteoblasts at bone-healing sites in rats. Oral Surg Oral Med Oral Pathol Oral Radiol Endod. 2009;107(3):336-42. https://doi.org/10.1016/j.tripleo.2008.07.013

10. Dai L, Xu M, Wu H, Xue L, Yuan D, Wang Y et al. The functional mechanism of simvastatin in experimental osteoporosis. J Bone Miner Metab. 2016;34(1):23-32. https://doi.org/10.1007/s00774-014-0638-y

11. Montero J, Manzano G, Albaladejo A. The role of topical simvastatin on bone regeneration: A systematic review. J Clin Exp Dent. 2014;6(3):e286-90. https://doi.org/10.4317/jced.51415

12. Kaji H, Naito J, Inove Y, Sowa H, Sugimoto T, Chihara K. Statin suppresses apoptosis in osteoblastic cells: role of transforming growth factor-beta-Smad3 pathway. Horm Metab Res. 2008;40(11):746-51. https://doi.org/10.1055/s-0028-1082051

13. Park JB. The use of simvastatin in bone regeneration. Med Oral Patol Oral Cir Bucal. 2009;14(9):e485-8.

14. Okamoto Y, Sonoyama W, Ono M, Akiyama K, Fujisawa T, Oshima $M$ et al. Simvastatin induces the odontogenic differentiation of human dental pulp stem cells in vitro and in vivo. J Endod. 2009;35(3):367-72. https://doi.org/10.1016/i.joen.2008.11.024

15. Lee SY, Min KS, Choi GW, Park JH, Park SH, Lee $\mathrm{SI}$ et al. Effects of simvastain and enamel matrix derivative on Portland cement with bismuth oxide-induced growth and odontoblastic differentiation in human dental pulp cells. J Endod. 2012;38(3):405-10. https://doi.org/10.1016/i.joen.2011.12.025

16. Varalakshmi PR, Kavitha M, Govindan R, Narasimhan S.

Effect of statins with $\alpha$-tricalcium phosphate on proliferation, differentiation, and mineralization of human dental pulp cells. J Endod. 2013;39(6):806-12. https://doi.org/10.1016/i.joen.2012.12.036

17. Miyazawa A, Matsuno T, Asano K, Tabata Y, Satoh T. Controlled release of simvastatin from biodegradable hydrogels promotes odontoblastic differentiation. Dent Mater J. 2015;34(4):466-74. https://doi.org/10.4012/dmi.2014-272

18. Karanxha L, Park SJ, Son WJ, Nör JE, Min KS. Combined effects of simvastatin and enamel matrix derivative on odontoblastic differentiation of human dental pulp cells. J Endod. 2013;39(1):76-82. https://doi.org/10.1016/i.joen.2012.10.013

19. Chen PY, Sun JS, Tsuang YH, Chen MH, Weng PW, Lin FH. Simvastatin promotes osteoblast viability and differentiation via Ras/Smad/Erk/BMP-2 signaling pathway. Nutr Res. 2010;30(3):191-9. https://doi.org/10.1016/i.nutres.2010.03.004

20. Kim IS, Jeong BC, Kim OS, Kim YJ, Lee SE, Lee KN et al. Lactone form 3-hydroxy-3-methylglutaryl-coenzyme A reductase inhibitors (statins) stimulate the osteoblastic differentiation of mouse periodontal ligament cells via the ERK pathway. J Periodontal Res. 2011;46(2):204-13. https://doi.org/10.1111/j.1600-0765.2010.01329.x

21. Asl Aminabadi N, Maljaei E, Erfanparast L, Ala Aghbali A, Hamishehkar H, Najafpour E. Simvastatin versus calcium hydroxide direct pulp capping of human primary molars: a randomized clinical trial. J Dent Res Dent Clin Dent Prospects. 2013;7(1):8-14.

22. Jia $W$, Zhao $Y$, Yang J, Wang W, Wang $X$, Ling $L$ et al. Simvastatin promotes dental pulp stem cell-induced coronal pulp regeneration in pulpotomized teeth. J Endod. 2016;42(7):1049-54. https://doi.org/10.1016/i.joen.2016.03.007 
23. Ferracane JL, Cooper PR, Smith AJ. Can interaction of materials with the dentin-pulp complex contribute to dentin regeneration? Odontology. 2010;98(1):2-14. https://doi.org/10.1007/s10266-009-0116-5

24. de Souza Costa CA, Hebling J, Scheffel DL, Soares DG, Basso FG, Ribeiro AP. Methods to evaluate and strategies to improve the biocompatibility of dental materials and operative techniques. Dent Mater. 2014;30(7):769-84. https://doi.org/10.1016/i.dental.2014.04.010

25. Hanks CT, Sun ZL, Fang DN, Edwards CA, Wataha JC, Ritchie $\mathrm{HH}$ et al. Cloned 3T6 cell line from CD-1 mouse fetal molar dental papillae. Connect Tissue Res. 1998;37(3-4):23349. https://doi.org/10.3109/03008209809002442

26. Soares DG, Brito CA, Tavares da Silva RH, Ribeiro AP, Hebling J, de Souza Costa CA. Cytocompatibility of HEMA-free resin-based luting cements according to application protocols on dentine surfaces. Int Endod J. 2016;49(6):551-60. https://doi.org/10.1111/iej.12479

27. International Standard Organization. ISO 10993-5:2009 (E). Biological evaluation of medical devices. Part 5: Tests for in vitro cytotoxicity. 3th ed. Genebra: International Standard Organization; 2009.

28. Soares DG, Basso FG, Scheffel DS, Hebling J, Costa CAS. Responses of human dental pulp cells after application of a low-concentration bleaching gel to enamel. Arch Oral Biol. 2015;60(9):1428-36. https://doi.org/10.1016/i.archoralbio.2015.06.014

29. Saewong S, Thammasitboon K, Wattanaroonwong N. Simvastatin induces apoptosis and disruption of the actin cytoskeleton in human dental pulp cells and periodontal ligament fibroblasts. Arch Oral Biol. 2013;58(8):964-74. https://doi.org/10.1016/i.archoralbio.2013.03.002
30. Meyers CD, Tannock LR, Wight TN, Chait A. Statin-exposed vascular smooth muscle cells secrete proteoglycans with decreased binding affinity for LDL. J Lipid Res. 2003;44(11):2152-60. https://doi.org/10.1194/ilr.M300252-JLR200

31. Tanaka T, Tatsuno I, Uchida D, Moroo I, Morio H, Nakamura $\mathrm{S}$ et al. Geranylgeranyl-pyrophosphate, an isoprenoid of mevalonate cascade, is a critical compound for rat primary cultured cortical neurons to protect the cell death induced by 3-hydroxy-3-methylglutaryl-CoA reductase inhibition. J Neurosci. 2000;20(8):2852-9.

32. Baek KH, Lee WY, Oh KW, Tae HJ, Lee JM, Lee EJ et al. The effect of simvastatin on the proliferation and differentiation of human bone marrow stromal cells. J Korean Med Sci. 2005;20(3):438-44. https://doi.org/10.3346/jkms.2005.20.3.438

33. Pullisaar H, Reseland JE, Haugen HJ, Brinchmann JE, Ostrup E. Simvastatin coating of $\mathrm{TiO}_{2}$ scaffold induces osteogenic differentiation of human adipose tissue-derived mesenchymal stem cells. Biochem Biophys Res Commun. 2014;447(1):139-44. https://doi.org/10.1016/i.bbrc.2014.03.133

34. Thylin MR, McConnell JC, Schmid MJ, Reckling RR, Ojha J, Bhattacharyya I et al. Effects of simvastatin gels on murine calvarial bone. J Periodontol. 2002;73(10):1141-8. https://doi.org/10.1902/jop.2002.73.10.1141

35. Wang JW, Xu SW, Yang DS, Lv RK. Locally applied simvastatin promotes fracture healing in ovariectomized rat. Osteoporos Int. 2007;18(12):1641-50. https://doi.org/10.1007/s00198-007-0412-2

36. Stein D, Lee Y, Schmid MJ, Killpack B, Genrich MA, Narayana $\mathrm{N}$ et al. Local simvastatin effects on mandibular bone growth and inflammation. J Periodontol. 2005;76(11):1861-70. https://doi.org/10.1902/jop.2005.76.11.1861 